\title{
Effect of Time of Planting on Yields and Processing Characteristics of Plantains
}

\author{
F. Sanchez Nieva, I. Hernández, R. Guadlalupe, and C. Bueso ${ }^{1}$
}

\section{INTRODUCTION}

Plantain processing has become an important operation during the last decade for the food processing industry in Puerto Rico. In $1966(1),{ }^{2}$ $3,168,000$ plantains were processed, and the total value of the processed products amounted to $\$ 894,165$. Establishment of new processing plants after 1966 and a continuing good market for processed plantain products indicates need for increasing plantain production to supply demand for both processing and fresh market.

From the processing standpoint, it would be highly desirable to spread production as uniformly as possible throughout the year and at the same time maintain fruit quality. Plantains presently are generally available throughout the year, but there is a summer surplus and scanty production during fall and winter months. Consumers in general regard quality of spring and summer plantains much higher than those produced during other seasons of the year.

No information is available to indicate the feasibility of producing good quality plantains for processing throughout the year with profitable yields to the farmer. Such information is extremely desirable. Studies therefore were conducted to furnish such basic data by establishing monthly plantings and determining the effect of time of harvesting on yield, quality and processing characteristics of the resulting fruit.

\section{MATEIRIALS AND METIODS}

The experimental plantings for these investigations were established at the Corozal Substation using a Maricongo cultivar grown commercially in the Naranjito area. Monthly plantings of approximately 108 plants each were established at 30-day intervals. The first planting was established in April 1967, the last in March 1968.

The plants were established at intervals of 5 feet in rows 8 feet apart. Uniform-sized corms weighing an average of 4.5 pounds were used. The

${ }^{1}$ Associate Director, Agricultural Experiment Station, Assistant Chemical Engineer, Assistant Horticulturist, and Assistant Food Technologist, respectively, Food Technology Laboratory, Agricultural Experiment Station, Mayagïez Campus, University of Puerto Rieo, Río Piedras, P.R. The authors wish to express their gratitude to the staff of the Corozal Substation for their assistance in the field experiments.

2 Italic numbers in parentheses refer to Literature Cited, p. 404. 
corms were peeled and dipped in a solution of 1 gallon of 25-percent Aldrin in 50 gallons of water to control the banana borer Cosmopolites sordiclus $\mathrm{G}$. After tilling, about 6 pounds of sugarcane filter press cake were added per hole and then treated with the Aldrin solution.

Fertilizer formula 8-8-13 was applied at the rate of 1 pound per plant, together with 3 ounces of ammonium sulfate 60 days after planting and at 60 -day intervals thereafter until shooting. Soil $\mathrm{pH}$ was adjusted to 6.0 by liming. Six months after planting, the soil was again treated with the Aldrin solution. No suckers were allowed to grow and weeds were removed with a hoe as needed. The plants were sprayed with orchard spray oil every 15 days to control the Sigatoka leaf-spot disease caused by the fungus Cercospora musae. Double alternate rows of the Enano cultivar were planted around each planting at a distance of 4 feet $x 4$ feet to serve as windbreak.

Twenty-four plants were selected at random from each planting to measure rate of growth and to determine height and number of functional leaves at shooting and harvesting. Dates of shooting were recorded. Bunches were harvested when the pulp content reached about 60 percent (pulp to peel ratio of 1.5).

To determine proper time of harvesting, a number of bunches w ere selected at random among those which shot within a calendar month and samples of fruit from the third hand (basal) were taken 40 days after shooting, and at frequent intervals thereafter until the pulp content reached 60 percent. For processing, all bunches were harvested at the same age when random samples attained a pulp content of 60 percent.

All bunches harvested were weighed with the stem cut off about 6 inches from the first (basal) hand and about 1-inch from the last (distal) hand. Hands and fingers were counted. Fingers from the third (basal) hand were sampled to determine pulp content, fruit weight, cross sectional measurements and texture.

Texture was measured with a Food Technology Corporation electrical recording and indicating texture instrument with a 3,000-pound proving ring and with the range set for 1,500 pounds. A standard shear cell was used for all determinations. To make a measurement, the plantains were peeled by hand and cut in halves lengthwise. The slices were cut in length to fit the cell and placed perpendicular to the path of the knives. The cell was packed full, which generally required about $\$$ ounces of the sliced fruit. The plunger was adjusted to 1-minute stroke, and the time-force curve was recorded and the maximum force applied was read directly from the chart.

For processing, the fruit was detached from the stems and weighed. It then was treated in steam at 80 p.s.i.g. for 30 seconds to loosen the peel. After the steam treatment, the fruit was cooled with water sprays and the loose peel removed by hand. The peeled fruit was cut crosswise into 1-inch 
thick slices. The slices were steam-blanched for 2 minutes, cooled with water sprays, then sulfited to avoid browning by dipping for 4 minutes in a 0.6 -percent-by-weight $\mathrm{K}_{2} \mathrm{~S}_{2} \mathrm{O}_{5}$ solution. The sulfited slices were packed in Marathon waxed containers which were overwrapped with vapor-moisture proof, heat sealable paper. The slices were frozen at $-40^{\circ} \mathrm{F} .\left(-40^{\circ} \mathrm{C}\right.$. $)$ in a plate freezer and stored at $-10^{\circ} \mathrm{F} .\left(-23.3^{\circ} \mathrm{C}\right.$.). For evaluation, the slices were fried without thawing for 8 minutes at $350^{\circ} \mathrm{F}$. (176.7 $7^{\circ} \mathrm{C}$.). The fried slices were pressed in a hand press to about $5 / 8$-inch thickness and fried a second

TABLE 1.-Planting and shooling dales and characteristics of the flowering period for the 12 plantings

\begin{tabular}{|c|c|c|c|c|c|c|}
\hline \multirow[b]{2}{*}{ Planting } & \multirow[b]{2}{*}{ Planting datc } & \multirow[b]{2}{*}{ Date of first inflorescence } & \multicolumn{3}{|c|}{$\begin{array}{l}\text { Interval from planting to } \\
\text { shooting }\end{array}$} & \multirow{2}{*}{$\begin{array}{l}\text { Difference } \\
\text { between } \\
\text { earliest } \\
\text { and lates } \\
\text { fowering } \\
\text { plants }\end{array}$} \\
\hline & & & Range & Mean & $\begin{array}{l}\text { Stand- } \\
\text { ard } \\
\text { devia- } \\
\text { tion }\end{array}$ & \\
\hline umber & & & Days & Days & Days & Days \\
\hline 1 & April 25, 1967 & March 22, 1968 & $331-453$ & 392 & 27 & 122 \\
\hline 2 & May 25, 1967 & March 22, 1968 & $301-413$ & 348 & 22 & 112 \\
\hline 3 & June 28, 1967 & May 1, 1968 & $307-412$ & 352 & 24 & 105 \\
\hline 4 & July 26, 1967 & May 3, 1968 & $281-371$ & 309 & 16 & 90 \\
\hline 5 & August 25, 1907 & May 28, 1968 & $276-400$ & 324 & 25 & 124 \\
\hline 6 & September 25, 1967 & June 6, 1968 & $245-344$ & 285 & 17 & 99 \\
\hline 7 & October 26,1967 & July 24,1968 & $271-434$ & 331 & 37 & 153 \\
\hline 8 & November 27, 1967 & September 3, 1968 & $280-406$ & 331 & 32 & 126 \\
\hline 9 & December 26, 1967 & September 24,1968 & $272-517$ & 373 & 52 & 245 \\
\hline 10 & January 25, 1968 & November 12,1968 & $291-468$ & 381 & 42 & 177 \\
\hline 11 & February 27,1968 & December 12,1968 & $288-433$ & 362 & 33 & 145 \\
\hline 12 & March 26, 1968 & February 11,1969 & $322-155$ & 385 & 26 & 133 \\
\hline
\end{tabular}

time for 4 minutes at $375^{\circ} \mathrm{F}$. $\left(190^{\circ} \mathrm{C}\right.$.). The fried slices were sensory appraised by the Kramer and Ditman's method (2).

\section{RESULTS AND DISCUSSION}

The data in table 1 shows the flowering pattern exhibited by each of the 12 monthly plantings. The average interval from planting to flowering decreased from 392 days from the first planting in April to 285 days for the sixth planting in September. The span of the flowering period for these plantings ranged from 90 to 124 days. The range between the dates of the first shootings of the first six plantings was 76 days, even though the interval was 5 months from the time of the first one planted to the time of the sixth. In the plantings planted from October to February, the interval from planting to blooming was more uniform as a result of which flowering of successive monthly plantings was more evenly spread. The flowering span in 
these plantings varied more than in the first six, and ranged from 126 to 245 days. As a result, some of the plantings continued to flower and bear fruit for as long as $\mathrm{S}$ months after flowering started. Rainfall and temperature data for the period from planting to harvesting is shown in figure 1. Weather conditions prevailing throughout the duration of the experiment were normal for this region.
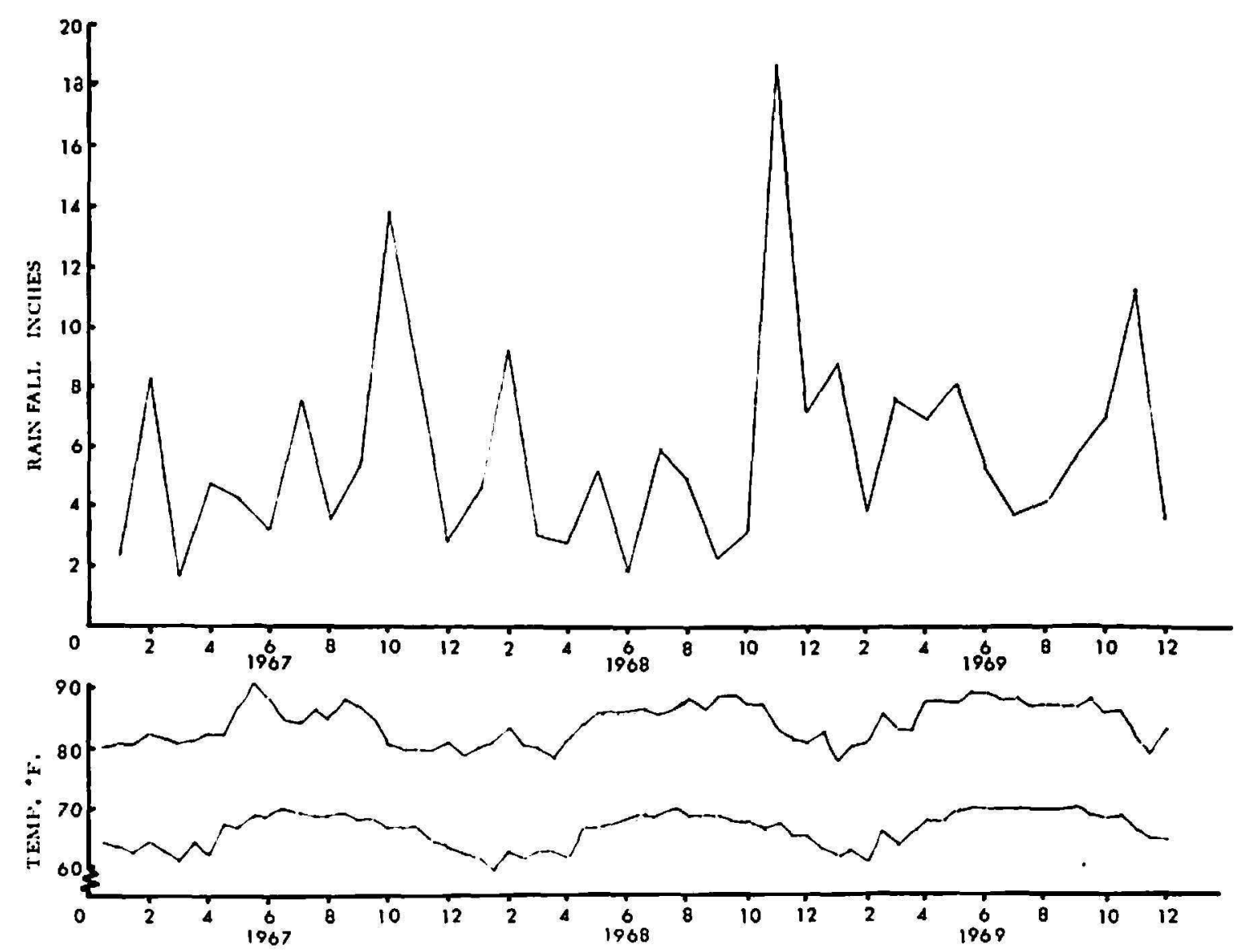

Fig. 1.-Temperature and rainfall data for the period from flowering to Harvesting.

Due to the flowering pat tern exhibited by the 12 plantings, it was possible to harvest fruit throughout the 12-month period, but a definite production peak resulted. This probably was due to a seasonal effect that cannot be avoided by establishing monthly plantings. The percentage distribution for all plants flowering for the duration of the experiment is shown in figure 2. Since plantains in all plots reached proper maturity level for harvesting in about 90 days, the production and harvesting pattern will be similar to the flowering pattern shown in figure 2 . A definite production peak was observed from July on, which lasted about 90 days. After the peak was over, a more uniform flowering distribution was observed, resulting in a more uniform production of fruit throughout the rest of the year. 
Table 2 shows the characteristics of the fruit harvested for each planting month. The age at harvesting, measured from shooting, ranged from 76.5 to 93.9 days for fruit with a pulp content ranging from 55.7 to 63.7 percent.

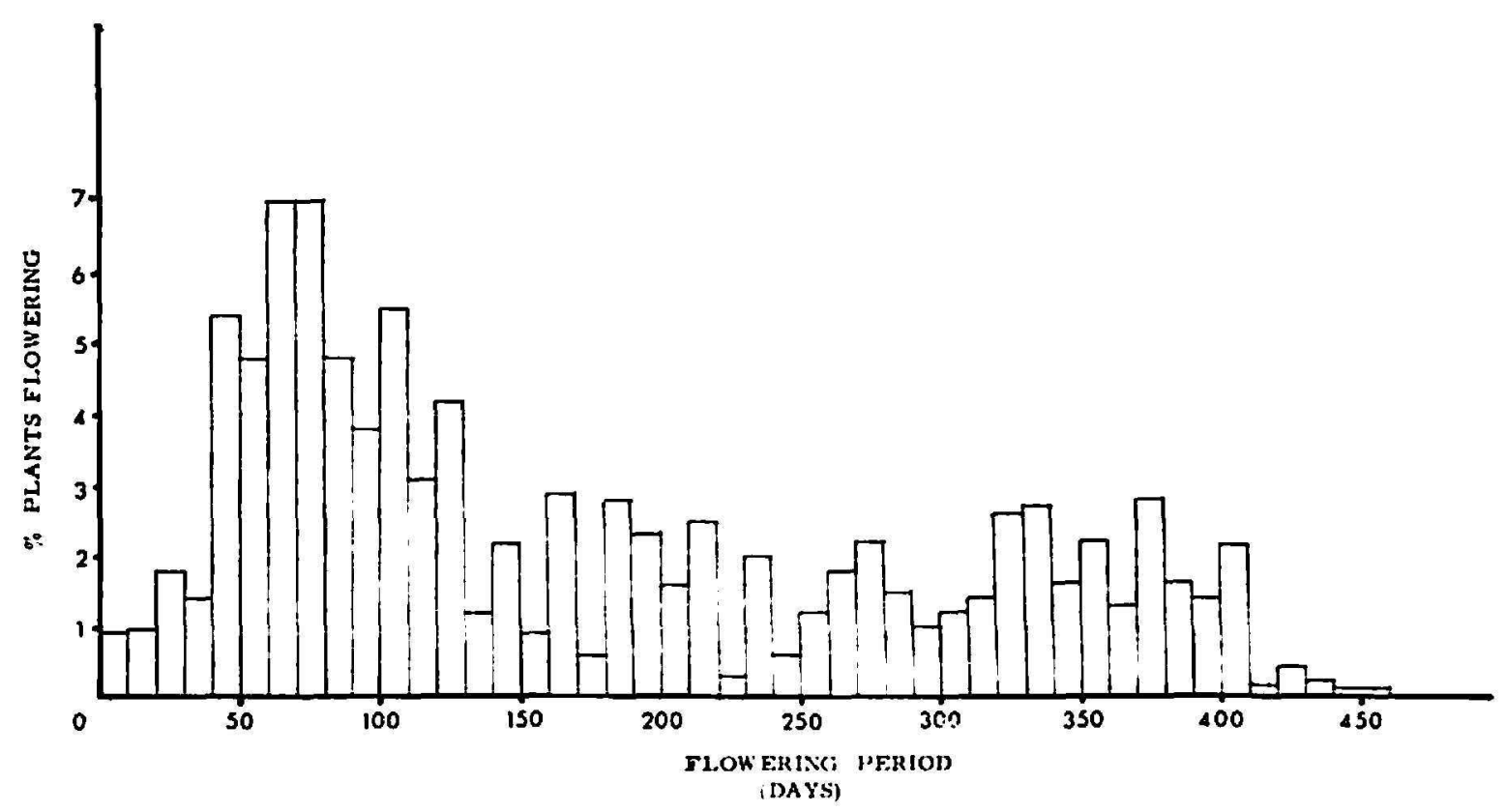

Frg. 2.-Percentage distribution of plants flowering in all 12 plantings throughout the study.

TABLE 2.-Characteristics of plantains harvested from monthly plantings

\begin{tabular}{lcccccc}
\hline Planting & $\begin{array}{c}\text { Age at } \\
\text { harvesting }\end{array}$ & $\begin{array}{c}\text { Average } \\
\text { weight of } \\
\text { bunch }\end{array}$ & $\begin{array}{c}\text { Average } \\
\text { weight of } \\
\text { fingers }\end{array}$ & $\begin{array}{c}\text { Pulp } \\
\text { content }\end{array}$ & $\begin{array}{c}\text { Fruits per } \\
\text { bunch }\end{array}$ & $\begin{array}{c}\text { Hands per } \\
\text { bunch }\end{array}$ \\
\hline Month & Days & Pounds & Grams & Percent & Number & Number \\
April & 88.7 & 19.8 & 294.3 & 62.8 & 31.0 & 6.1 \\
May & 92.5 & 24.5 & 290.7 & 62.7 & 37.7 & 6.5 \\
June & 84.5 & 23.7 & 233.9 & 61.2 & 44.5 & 6.9 \\
July & $\mathbf{8 7 . 2}$ & 23.5 & 277.5 & $\mathbf{6 3 . 7}$ & 39.2 & 6.5 \\
August & 79.1 & 20.2 & 231.4 & 58.8 & 39.8 & 6.9 \\
September & 76.5 & 19.9 & 212.5 & 55.7 & 22.8 & 6.2 \\
October & 92.4 & 19.7 & 216.8 & 60.4 & 39.7 & 6.8 \\
November & 92.8 & 20.9 & 190.1 & $\mathbf{5 8 . 9}$ & 45.1 & 7.0 \\
December & $\mathbf{9 3 . 7}$ & 18.1 & 209.5 & 59.0 & 36.5 & 6.3 \\
January & 93.9 & 19.3 & 229.5 & 59.8 & 36.9 & 6.1 \\
February & 90.7 & 20.7 & 245.2 & 60.8 & 36.1 & 6.0 \\
March & 79.9 & 17.8 & 234.0 & 59.1 & 34.6 & 6.0 \\
\hline
\end{tabular}

After shooting.

The average age for harvesting for all months was $\$ 7.6$ days. It should be observed from the data in this table that the plantains reached the same stage of development at about the same age after shooting irrespective of 
the time of planting and, hence, of harvesting. A lower pulp content resulted when harvesting was carried out at a lower age.

The number of fruits per bunch and the average weight of the fingers varied with the time of planting. The average weight of the fruit decreased from the April planting on to reach a minimum in the November planting, after which weight began to increase again.

The number of fruits per bunch varied in opposite fashion, the number of fruits increased as the weight of the fruit decreased.

Bunch weight ranged from 17.8 to 24.5 pounds with a trend to decrease from the August planting on. The plants of the last months of planting were

TAHLE 3.-Height of planls al shooling and number of functional leaves al the lime of shooling and harvesting

\begin{tabular}{lccc}
\hline \multirow{2}{*}{ Planting } & \multirow{2}{*}{ Average height } & \multicolumn{2}{c}{ Functional leaves } \\
\cline { 3 - 4 } & & At shooting & At harvest \\
\hline Month & Inches & Number & Number \\
April & 139.8 & 10.6 & 9.5 \\
May & 139.1 & 12.3 & 9.6 \\
June & 137.0 & 12.9 & 10.3 \\
July & 134.5 & 12.5 & 9.8 \\
August & 124.8 & 13.5 & 9.7 \\
September & 125.2 & 14.5 & 10.3 \\
October & 128.3 & 12.2 & 19.8 \\
November & 135.1 & 14.4 & 10.1 \\
December & 127.1 & 12.1 & 8.1 \\
January & 130.9 & 10.8 & 7.3 \\
February & 132.7 & 11.9 & 7.3 \\
March & 141.8 & 10.8 & 6.7 \\
\hline
\end{tabular}

affected more by Sigatoka and by soil pests than the first four, thus the decrease in bunch weights may be due more to plant health factors than to time of planting. The overall condition of each planting at shooting and harvesting is shown in table 3. A marked decrease was noted in the number of functional leaves at time of harvest in the last four plantings.

The characteristics of the fruit at harvest during each calendar month are shown in table 4 . The weight of the bunch with a pulp content of about 60 percent ranged from 15.1 to 25.0 pounds. The weight of the fingers ranged from 188.7 to $278.9 \mathrm{~g}$. and the number of fruit per bunch ranged from 29.0 to 43.7 .

The industrial characteristics of the fruit processed from each calendar month harvest are shown in table 5. The percentage of trimmings from the slicing operation, including trimmings due to defects, ranged from 9.8 to 15.2. The number of 1 -inch slices obtained from 100 fruits processed ranged 
from 374 to 516 and had a weight ranging from 19.8 to 33.5 pounds. The quality of the processed frozen slices remained acceptable throughout the year, as shown by the ratings of the test samples given in table 5 . Data reresulting from the Kramer and Ditman's method (2) for sensory evaluation used throughout these studies furnished a rating of no less than 0.5 , thus an indication that quality of the product was acceptable to the tasters.

From the point of view of the processor, the quality of the processed products remained acceptable throughout the year, but the variations in yields as reflected in the variations in bunch weight, number of fruits per bunch,

T.ABLE 4.-Characteristics of the fruit harvestcl each month from June 1968 to June 1969

\begin{tabular}{lcccccc}
\hline Month of harvest & $\begin{array}{c}\text { Age at } \\
\text { harvestingt }\end{array}$ & $\begin{array}{c}\text { Average } \\
\text { weight ci } \\
\text { bunch }\end{array}$ & $\begin{array}{c}\text { Average } \\
\text { weight of } \\
\text { Gngers }\end{array}$ & Pulp content & $\begin{array}{c}\text { Fruit per } \\
\text { bunch }\end{array}$ & $\begin{array}{c}\text { Hands per } \\
\text { bunch }\end{array}$ \\
\hline & Days & Pounds & Grams & Percent & Number & Number \\
\multicolumn{1}{c}{1968} & & & & & & \\
June & 71.3 & 15.1 & 236.1 & 54.9 & 30.2 & 6.2 \\
July & 93.3 & 25.0 & 277.1 & 61.3 & 40.6 & 6.6 \\
August & 87.0 & 23.2 & 278.9 & 63.4 & 37.8 & 6.4 \\
September & 78.0 & 20.4 & 222.7 & 58.5 & 42.0 & 6.6 \\
October & 81.4 & 20.5 & 208.3 & 57.4 & 42.3 & 7.3 \\
November & 98.0 & 17.3 & 239.7 & 61.6 & 28.3 & 7.1 \\
December & 93.5 & 20.6 & 222.4 & 60.2 & 40.9 & 6.8 \\
$\quad 1969$ & & & & & & \\
January & 92.4 & 20.4 & 188.7 & 60.0 & 43.7 & 7.1 \\
February & 95.0 & 15.5 & 189.9 & 59.1 & 34.9 & 5.7 \\
March & 95.0 & 20.1 & 208.3 & 57.8 & 42.5 & 6.6 \\
April & 94.2 & 15.7 & 229.9 & 59.3 & 29.0 & 6.0 \\
May & 92.4 & 21.0 & 245.0 & 60.8 & 37.9 & 5.9 \\
Jume & 77.7 & 19.2 & 239.3 & 60.1 & 35.7 & 6.0 \\
\hline
\end{tabular}

${ }^{1}$ After shooting.

and weight of the individual fruit, would be considered objectionable. In studies conducted by Sánchez-Nieva et al. (S) to determine the processing characteristics of the Maricongo and Guayamero cultivars, the weight of the bunches from a normal 3-month harvest from simple plantings ranged from 8.5 to 29.0 pounds. The number of fruits per bunch ranged from 12 to 57 and the weight of the fruit ranged from 132 to $380 \mathrm{~g}$. Therefore, the variation in these characteristics, as observed for all 12 plantings, are within the range of variation characteristic of presently planted commercial plantain clones, and no more uniformity can be expected unless better cultivars become available.

The results obtained by limiting the experiments to one location, one cultivar, and observations made in non-replicated plantings, prevent general- 
TABLE 5.-Industrial characteristics of fruit harvested

\begin{tabular}{|c|c|c|c|c|c|c|c|c|c|c|c|c|c|}
\hline \multirow{2}{*}{ Characteristic measured } & \multirow{2}{*}{ Units } & \multicolumn{12}{|c|}{ Month harvested } \\
\hline & & Aug. & Sept. & Oct. & Nov. & Dec. & Jan. & Feb. & Mar. & Apr. & May & Jun. & Jul. \\
\hline Average fruit weight & Ounces & 8.9 & 7.0 & 9.8 & 6.9 & 7.9 & 7.6 & 6.7 & 8.5 & 10.4 & 7.6 & 7.3 & 9.9 \\
\hline Pulp content & $\begin{array}{l}\text { Percent by } \\
\text { weight }\end{array}$ & 62.9 & 59.7 & 61.6 & 59.7 & 61.0 & 61.2 & 60.8 & 60.0 & 61.9 & 61.1 & 61.2 & 61.0 \\
\hline Trimmings & $\begin{array}{l}\text { Percent by } \\
\text { weight }\end{array}$ & 11.7 & 14.9 & 12.3 & 13.0 & 14.5 & 11.3 & 14.5 & 11.2 & 9.8 & 11.6 & 15.2 & 11.2 \\
\hline $\begin{array}{l}\text { Number of slices per } 100 \\
\text { fruit }\end{array}$ & Number & 510 & 489 & 481 & 37.4 & 404 & 436 & 403 & 476 & 497 & 457 & 411 & 508 \\
\hline $\begin{array}{c}\text { Weight of slices per } 100 \\
\text { fruit }\end{array}$ & Pounds & 28.9 & 25.4 & 29.2 & 21.3 & 23.4 & 25.2 & 19.8 & 28.2 & 33.5 & 25.4 & 23.2 & 33.0 \\
\hline Texture shear press force ${ }^{1}$ & Pounds & - & - & - & 一 & 970 & 955 & 994 & 1,239 & 1,110 & 945 & 930 & 905 \\
\hline Organoleptic rating ${ }^{2}$ & & .72 & .77 & .96 & .81 & 1.0 & 1.2 & 1.0 & .95 & .96 & 1.1 & .69 & 1.1 \\
\hline Fruit diameter & Inches & 1.37 & 1.31 & 1.31 & 1.37 & 1.37 & 1.31 & 1.25 & 1.37 & 1.37 & 1.37 & 1.37 & 1.37 \\
\hline
\end{tabular}

1 Texture measurements made using FTC Press with standard cell.

2 Rating for fried slices prepared from frozen plantain slices using \pm 2 scale. Average value for all lots processed. 
ization respecting behavior of plantains of different cultivars planted in other regions the year around. In spite of such limitation, several important conclusions can be derived from this study.

Peak production during the summer months seems to be seasonal with plantains. The only way to avoid excessive summer productions would be to schedule time of planting to spread production more evenly. Several planting schedules have been calculated based on flowering distribution data from the monthly plantings in these experiments.

The first schedule included monthly plantings during May and July and from August through March; the second, plantings during April, June, and August and from September through March; and the third, plantings during April, June, August, October, November, and from January through March. Flowering distribution for each of these three schedules are shown in figure 3. Schedule 1 is the only one which offers the possibility of spreading flowering and, hence, more even production during the year.

A second conclusion derived from this research is that processed products of acceptable quality can be prepared from fruit harvested throughout the year, provided the plantains are harvested at a proper stage of development. In previous studies by Sánchez et al. (4) and confirmed by our data, this corresponds to the stage at which the fruit reaches a pulp content of about 60 percent.

A third conclusion is that irrespective of the time of planting or harvesting, plantains reach a pulp content of about 60 percent within a period of approximately 80 to 90 days after shooting. Such uniformity in the development of the fruit would make it possible to schedule the harvest by determining the dates of shooting. This would eliminate need for using other harvesting indexes such as fullness of the fruit, pulp to peel ratio, or other texture measurements which, according to Sánchez et al. (4), proved either to be unreliable or inadequate for field use.

\section{SUMMARY}

Research was conducted to determine the feasibility of spreading plantain production for processing purposes throughout the year by establishing monthly plantings. The experiments were established at the Corozal Substation using a Maricongo-type commercial cultivar. The results obtained showed that when monthly plantings were established beginning in April 1967, the plantings established during the first six months started to bloom within a period of 76 days, reaching peak production during the summer. The fruit reached the proper stage for harvesting in about 90 days after shooting, irrespective of the time of planting. The processing quality of the fruit was not affected by the time of planting and harvesting. A sensory evaluation of frozen plantain slices prepared from fruit harvested during the 

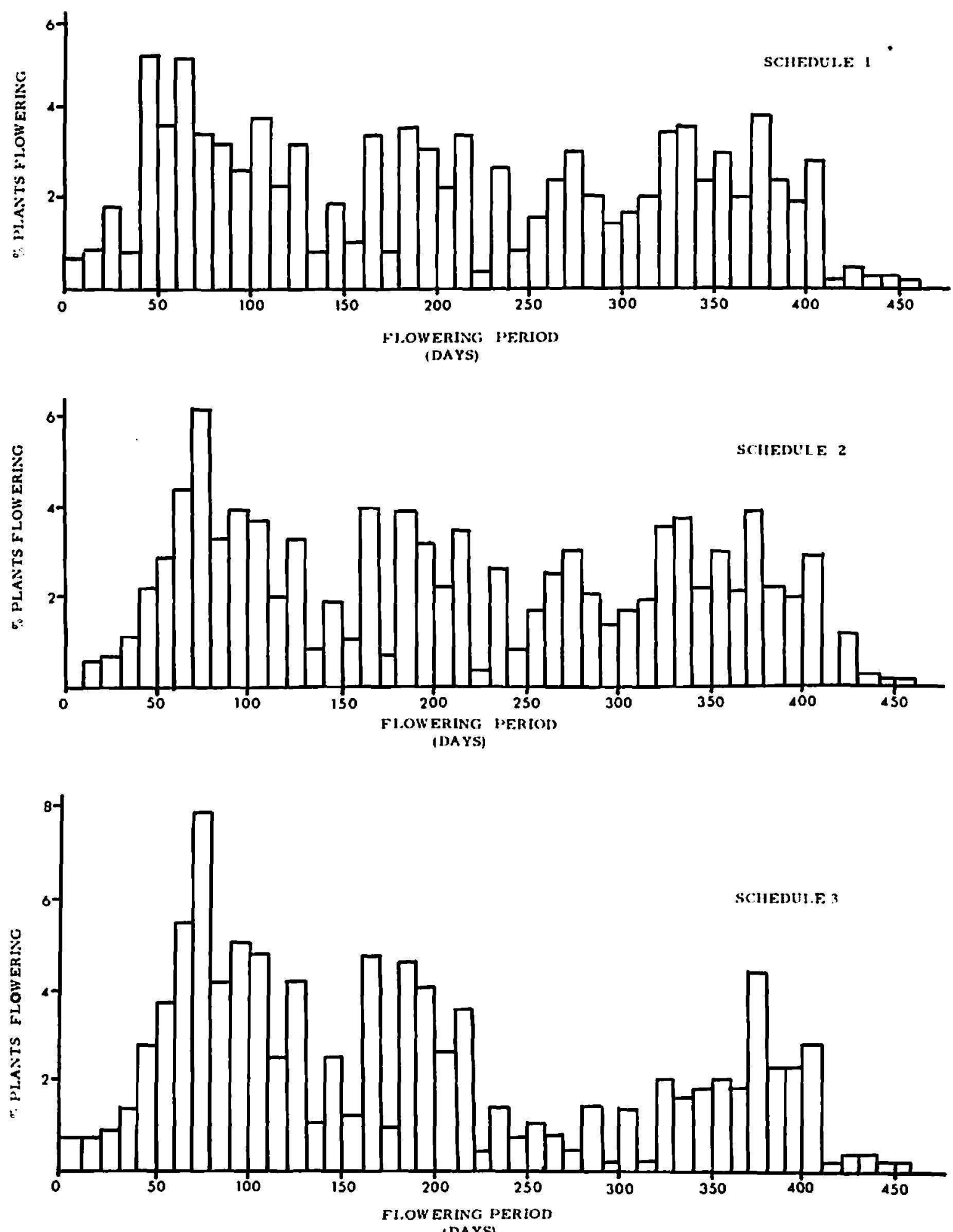

Fig. 3.-Calculated flowering patterus for three different planting schedules.

entire year showed that the quality of the processed frozen plantain slices was acceptable throughout a 12-month harvesting period, provided the fruit was harvested when its pulp content approximated 60 percent.

Variations in processing yields due to variations in the weight of the fruit 
and the number of fruits per bunch, which in turn resulted from seasonal effects, were within the limits considered normal for commercially-harvested fruit. The study suggests the possibility of spreading plantain production by scheduling the plantings to avoid the summer production peak.

\section{RESUMEN}

Se llevó a cabo un estudio para determinar si haciendo las siembras mensualmente es posible obtener una producción más uniforme de plátanos durante todo el año, a la vez que una fruta cle calidad aceptable para la elaboración. El estudio se llevó a cabo en la Subestación de Corozal, donde se sembró la variedad comercial del tipo conocido en Puerto Rico como Maricongo. Las siembras mensuales se hicieron comenzando en abril de 1967 y terminando en marzo de 1968. Las primeras seis siembras comenzaron a florecer dentro de un periodo de $\mathbf{7 6}$ días entre la primera y la sexta, lo cual dió lugar a que durante los meses del verano se produjera una cantidad mayor de frutus que durante el resto del año.

La fruta cosechada durante el periodo de 12 meses se utilizó para preparar tostones congelados. La calidad del producto no varió durante el año, según las pruebas organolépticas a que se sometieron las muestras. Aunque la estación del año tuvo que ver con el peso de los racimos y el número de frutas por racimo, el rendimiento industrial se mantuvo dentro de los limites que se consideran normales para los plátanos que se cosechan para fines comerciales.

Este estudio sugiere la posibilidad de distribuir la producción durante el año más uniformemente, evitando así que ésta se limite al apogeo usual que ocurre en el verano, si en vez de hacer las siembras mensualmente se hacen alternadas, de acuerdo con tres programas distintos que se sugieren.

\section{LITEIRATURE CITED}

1. Cionzález-Villafañe, E., listudio sobre el uso industrial de las frutas y vegetales en Puerto Rico, Agr. lixp. Sta., Mayagüez Campus, Univ. P.1R., Bull. 222, 1970.

2. Kramer, A., and Ditman, I. P., A simplified variable taste panel method for detecting flavor changes in vegetables treated with pesticides, Food Tech. 10: 155-9, 1956.

3. Sánchez-Nieva, F., Hernández, I., Colom-Covas, G., (iuadalupe-Iıua, R., Díaz, N., and Viñas, C. B., A comparative study of some characteristics of two plantain cultivars which affect yield and product quality, J. Agr. Univ. P.R., 52 (4): 323-38, 1968.

4. Sánchez-Nieva, F., llernández, I., Colom-Covas, (i., Guadalupe-Luna, R., Díaz, N., and Viñas, C. B., Preharvest changes in the physical and chemical properties of plantains, J. Agr. Univ. P.R., 52 (3): 241-55, 1968. 